\title{
A atuação de Dom Jaime Luiz Coelho na Diocese de Maringá: fronteiras sucessivas em Paranavaí (1956-1979)
}

\section{The performance of Don Jaime Luiz Coelho in the Diocese of Maringá: successive frontiers in Paranavaí (1956-1979)}

\author{
Leide Barbosa Rocha Schuelter ${ }^{*}$ \\ https://orcid.org/0000-0002-9291-9174
}

\begin{abstract}
Resumo
a proposta deste artigo é refletir sobre o papel desempenhado por Dom Jaime Luiz Coelho, bispo (1957-1979) e arcebispo (1979-1997) de Maringá$\mathrm{PR}$, pontuando sua atuação à frente das paróquias durante o período em que Paranavaí pertenceu à Diocese de Maringá. E, especificamente, pontuar a conduta do bispo em relação aos freis da Província Carmelita de Bamberg, missionários precursores que integraram o amplo processo de desenvolvimento da instituição católica no Paraná. 0 texto analisa a edificação da instituição católica no Paraná como parte de um processo de desenvolvimento territorial, demográfico e civilizador do estado, tendo por base o conceito de fé e territorialidade proposto pela geografia cultural. A criação da Diocese de Paranavaí, desmembrada da Diocese de Maringá sob o bispado de Dom Jaime e a liderança dos freis carmelitas, oportuniza concluir que a história da Igreja Católica no Norte e Norte Novíssimo do Paraná e o desenvolvimento históricosocial da região são processos atrelados à presença eclesiástica portadora de um projeto civilizador.
\end{abstract}

Palavras-chave: Dom Jaime; Carmelitas; Diocese de Paranavaí; Projeto Civilizador.

\begin{abstract}
The purpose of this article is to reflect on the role played by Bishop Jaime Luiz Coelho, bishop (1957-1979) and Archbishop (1979-1997) of Maringá-PR, punctuating his performance in front of parishes during the period in which Paranavaí belonged to the Diocese of Maringá. And specifically, to point out the conduct of the bishop in relation to the friars of the Carmelite Province of Bamberg, precursor missionaries who integrated the broad process of development of the Catholic institution in Paraná. The text analyzes the construction of the Catholic institution in Paraná as part of a process of
\end{abstract}

\footnotetext{
*Doutoranda em História do curso de Pós-Graduação em História da Universidade Estadual de Maringá (UEM).E-mail: leideschuelter@hotmail.com
} 
territorial, demographic, and civilizing development of the state, based on the concept of faith and territoriality proposed by cultural geography. The creation of the Diocese of Paranavaí, dismembered from the Diocese of Maringá, under the bishopric of Don Jaime and the leadership of the Carmelite friar, leads to conclude that the history of the Catholic Church in the New North and North of Paraná and the historical-social development of the region are processes linked to the ecclesiastical presence, carrying a civilizing project.

Keywords: Don Jaime; Carmelites; Diocese of Paranavai; Civilizing Project.

\section{Considerações iniciais}

Em 1936 os carmelitas ${ }^{1}$ da Província de Bamberg, na Alemanha, sentiam-se movidos pelo ideal de abrir novos espaços de influência da Ordem. A expansão do campo religioso justificava-se pelo ideal missionário de retomada das pessoas afastadas dos preceitos cristãos, aproximando-as do sagrado. Vir da Alemanha para as terras desconhecidas do Brasil atendia a um dos pilares da Ordem Carmelita: a missão.

A vinda dos carmelitas para o Brasil, em missão, está relacionada aos componentes contextuais do século XX, referentes à Igreja e às mudanças advindas com o Modernismo. A crise da Igreja Católica mediante as transformações conceituais da sociedade atingia também a Ordem.

O primeiro passo foi dado em 1936 quando Ulrico Goevert ${ }^{2}$ embarcou na Alemanha rumo ao Brasil. Missionário carmelita enviado pela Província Carmelita de Bamberg, Alemanha, para trabalhar inicialmente em Recife-PE, Goevert tinha a incumbência de conhecer os costumes brasileiros, aprender a língua, para posteriormente iniciar a abertura de uma zona missionária que ficasse sob a tutela da Ordem carmelitana alemã. A Oberdeutsche Provinz der

\footnotetext{
${ }^{1}$ A ordem dos Irmãos da Bem-Aventurada Virgem Maria do Monte Carmelo, também chamada de Ordem dos Carmelitas Calçados, ou ainda, Carmelitas da Antiga Observância, para se diferenciarem posteriormente dos Carmelitas Descalços, é identificada pela sigla canônica O. Carm. Fundada no Monte Carmelo, próximo a Haifa, em Israel, sua regra foi escrita entre 1206 e 1214, período em que "Santo Alberto, Patriarca de Jerusalém, dá-lhes uma Regra escrita e reúne-os perto da fonte de Elias, sob a obediência de Brocardo [...], primeiro Superior Geral da Ordem Carmelita. In: GOMES, Jesué Pinharanda. Carmelitas calçados. In: FRANCO, Jose Eduardo. Dicionário histórico das Ordens: Institutos religiosos e outras formas de vida consagrada católica em Portugal: Gradiva, 2008. p .77.

${ }^{2}$ Hubert Goevert, conhecido no Brasil como Ulrico Goevert, nasceu em Darfeld, Província da Westfália, Alemanha, em 13 de julho de 1902. Foi o primeiro missionário Carmelita pertencente à Província Carmelita de Bamberg a ser enviado ao Brasil. (ARQUIVO PESSOAL DOM WILMAR SANTIN).
} 
Karmeliten, doravante denominada Província Carmelita de Bamberg, fica no estado da Baviera, localizado a sudeste da Alemanha.

Em contato com Dom Geraldo de Proença Sigaud, bispo da Diocese de Jacarezinho (1947-1961), Frei Ulrico Goevert firmou o propósito de abrir um campo misionário em Paranavaí-PR, pelos idos da década de 1950. Foram enviados os carmelitas missionários ${ }^{3}$ que, sob a liderança de Frei Ulrico, ocuparam o campo missionário de Paranavaí. Em meados do século XX, em meio à colonização do território conhecido como Norte Novíssimo, os carmelitas fizeram-se presentes ao processo civilizador da região.

Cabe esclarecer que o processo civilizador, neste texto, é pensado como um processo empreendido pelo Estado e Igreja que, comumente, buscaram incutir na sociedade em formação seus valores e princípios. Norbert Elias ${ }^{4}$, alicerça tal consideração com a defesa de que o processo civilizador emergido pela Modernidade contou com a intervenção dessas instituições, ora aliadas, ora em confronto. Isto se justifica porque na década de 1950 e 1960 deu-se a efetiva ocupação do Norte e Norte Novíssimo do Paraná. Nesse contexto, os carmelitas inserem-se como um grupo de religiosos que se estabeleceram com o objetivo de incutir novos modelos comportamentais.

Este texto apresenta a relação estabelecida entre Dom Jaime, bispo de Maringá, e os freis carmelitas, pontuando os conflitos existentes entre os poderes simbólicos religiosos na região de Paranavaí. Apresenta Dom Jaime, e propõe refletir seu papel no desenvolvimento da região Norte e Norte Novíssimo do Paraná.

O texto parte da hipótese de que o projeto de expansão do catolicismo e o processo civilizador da região mesclaram-se, criando uma realidade qual não é possível separar o avanço do modelo civilizador, que se estabeleceu, do crescimento do catolicismo institucionalizado na região.

A reunião do aporte teórico, dos documentos eclesiais locais, e a análise das narrativas produzidas pelos freis carmelitas permitem indicar a pesquisa qualitativa, concluindo que o processo de ereção do catolicismo na região,

\footnotetext{
${ }^{3}$ Ao todo foram 15 freis carmelitas alemães que introjetaram-se ao processo de construção da sociedade paranavaiense e região. Durante os primeiros 19 anos de administração da Província Carmelita de Bamberg foram enviados para trabalhar no Comissariado do Paraná um total de 14 religiosos. Se contarmos Frei Ulrico (1936), totalizamos 15. In: KNOBLAUCH, Joaquim. Os 25 anos dos carmelitas da Província Germaniae Superioris no Brasil. Paranavaí-PR, [s.n.] 1976, p. 06.
}

${ }^{4}$ ELIAS, Norbert. O Processo Civilizador: Formação do Estado e Civilização. RJ: Zahar, 1993. 
culminando na formação da Diocese de Paranavaí, é explicado pelo conceito de fronteiras sucessivas, tomado à pesquisa de Rosendhal. ${ }^{5}$

\section{O Processo de Institucionalização do Catolicismo em Paranavaí-PR}

Ao refletir sobre o processo de institucionalização do catolicismo em Paranavaí, a partir da presença dos freis carmelitas e a submissão ao bispo da Diocese de Maringá, percebe-se que os religiosos estiveram em constante luta, ainda que de maneira velada. Não há como negar a existência de disputas pela aquisição de espaço sagrado ou, pensando a partir de Bourdieu, do capital simbólico. ${ }^{6}$ Este autor oportuniza pensar a disputa pela conquista ou manutenção do poder na região de Paranavaí como um campo de forças onde o confronto dos agentes sociais determina o contexto.

Cabe pensar a edificação da instituição católica no Paraná como parte de um processo de desenvolvimento territorial, demográfico e civilizador do estado, conforme o conceito de fé e territorialidade exposto pela geografia cultural, e utilizado por historiadores das religiões e religiosidades. ${ }^{7}$ Estudiosa da Geografia da Religião, Rosendahl afirma que a "fé católica no contexto político-religioso é o ponto de partida para o entendimento do território brasileiro". 8

Não obstante, a história da cidade de Maringá-PR, a partir da fundação da diocese (1956), está estreitamente ligada à figura de Dom Jaime Luiz Coelho. Como Dom Jaime administrava também a região de Paranavaí, suas atitudes repercutiram na formação da sociedade paranavaiense. Compreende-se que a história da Igreja Católica no Norte e Norte Novíssimo do Paraná mescla-se

\footnotetext{
${ }^{5}$ A pesquisadora, de maneira geral, conceitua fronteiras sucessivas como uma estratégia de ocupação - ocorrida no Paraná - por meio da qual a Igreja Católica acompanhava cada expansão territorial com a abertura de novos campos religiosos. In: ROSENDAHL, Zeny. Primeira a obrigação depois a devoção: estratégias espaciais da Igreja Católica no Brasil de 1500 a 2005. Rio de Janeiro: EdUERJ, 2012.p. 136.

${ }^{6}$ BOURDIEU, Pierre.A Economia das trocas simbólicas. São Paulo. Perspectivas, 2011.

${ }^{7}$ A respeito da Geografia Cultural adentrar os campos da historiografia, e mais, da história das religiões e religiosidades, Rosendhal (2005, p.12928) explica que : "Na primeira metade do século XX, a temática é investigada por Paul Fickeler (1999 [1947]), que realiza um excelente estudo sobre questões fundamentais na Geografia da Religião em Grundfragen der Religions Geographie; por Pierre Deffontaines, na obra Geographie et Religions, em 1948 e por Maxmilien Sorre, que evidencia os elementos religiosos nos textos geográficos em Rencontres de la Géographie et de la Sociologie (1957)." In: ROSENDAHL, Z. Território e territorialidade: uma perspectiva geográfica para o estudo da religião. Anais do X Encontro de Geógrafos da América Latina - 20 a 26 de março de 2005 - Universidade de São Paulo, 20-26 março 2005. Disponivel em: http://observatoriogeograficoamericalatina.org.mx/egal10/Geografiasocioeconomica/ Geografiacultural/38.pdf. Acesso em: 27 maio 2020.
}

${ }^{8}$ Ibidem, p. 12928. 
ao desenvolvimento histórico-social da região. Desenvolvimento considerado tardio, em relação ao restante do estado, a (re) ocupação e a expansão desse território são processos atrelados à presença eclesiástica portadora de um projeto civilizador.

Divisão regional do norte do Paraná. ${ }^{9}$

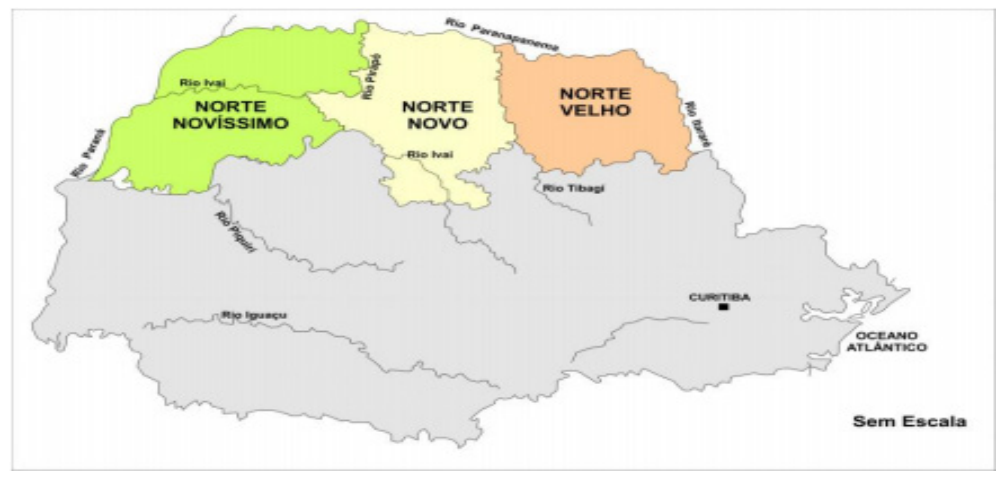

Em relação à criação de dioceses no Estado do Paraná, Rosendahl ${ }^{10}$ destaca que as iniciativas estiveram sempre ligadas aos movimentos de frentes pioneiras. Segundo a autora, até 1930 o Paraná tinha apenas três dioceses: Curitiba, Jacarezinho e Ponta Grossa. A partir de 1931 foram criadas mais 14 dioceses. A autora ressalta:

A ação da Igreja Católica acompanhava cada fronteira de ocupação que surgia. Quer na função de paróquia, na de colégio, ou na criação de prelazia, a instituição religiosa imprimia a ação evangelizadora e administrativa no lugar. Na maioria das vezes, por processo de fragmentação, novas dioceses eram criadas; estas por sua vez, continuavam esse processo, sucessivamente, até que todo território paranaense estivesse sob controle da Igreja. Esse comportamento pode ser definido como um tipo singular de estratégia de ocupação adotado pela Igreja Católica no Paraná, denominado fronteiras sucessivas. ${ }^{11}$

\footnotetext{
${ }^{9}$ DIVISÃO regional do norte do Paraná. Portal dos municípios. Disponivel em: http://observatoriogeograficoamericalatina.org.mx/egal10/Geografiasocioeconomica/Geografiacultural/38.pdf. Acesso em: 27 maio 2020.

${ }^{10}$ ROSENDAHL, Primeiro a obrigação... op. cit., p. 136.

${ }^{11}$ Ibidem.
} 
A criação de novas dioceses no Paraná, em meados do século XX, obedeceu a lógica da expansão territorial e crescimento populacional, devido a oportunidades econômicas estabelecidas pela cultura do café. Em decorrência da abertura tardia, a possibilidade de adquirir um pedaço de terra, e a demanda de mão de obra, foram condições que atraíram pessoas de várias localidades do Brasil. É nesse contexto que se insere a criação da Diocese de Maringá, em 1956, da qual Paranavaí passou a fazer parte. ${ }^{12}$

Atenta ao crescimento social, a Igreja não se furtou de participar dessa evolução, organizando a instituição estrategicamente, conforme o conceito de fronteiras sucessivas apontado. Isso significa que a atuação da Igreja jamais fora restrita a estruturar seu campo interno em meio ao processo civilizador, mas sim, embrenhar-se como agente ativo do processo. Ampliar as fronteiras do religioso respondia à necessidade de imputar a moral e a ética cristãs ao processo civilizador. Portanto, a Igreja passou a incentivar, abrir e liderar frentes sociais, como por exemplo, as Frentes Agrárias no Brasil, nos inícios dos anos $1960 .{ }^{13}$ No caso do Paraná em expansão cafeeira, a Igreja investe na Frente Agrária Paranaense (FAP): “No Paraná, a Frente Agrária Paranaense (FAP) foi articulada pelos bispos de Londrina, Jacarezinho, Maringá e Campo Mourão, com o objetivo de proporcionar condições mais humanas de vida na lavoura". ${ }^{14}$

Outro exemplo da inserção do clero na formação social foi a iniciativa de Dom Jaime Luiz Coelho ao erigir o Jornal Folha do Norte do Paraná, em 1962. O Jornal, sem cunho religioso, a princípio, apresentava-se como um veículo de informação secular. De acordo com Brito, Dom Jaime ambicionava torná-lo em um dos maiores do interior do Brasil para fazer frente ao jornal 'Última Hora' de Samuel Wainer"15. "Mais que um veículo de informação, o bispo almejava fazer do Jornal um porta voz da Igreja católica". ${ }^{16}$ Isto demonstra que a estratégia de expansão religiosa de Dom Jaime fazia frente às demandas civilizacionais do território em expansão.

\footnotetext{
${ }^{12}$ CÚRIA METROPOLITANA DE MARINGÁ, 1956, p.1.

${ }^{13}$ PRIORI, Ângelo [et al.]. História do Paraná: séculos XIX e XX. Maringá: Eduem, 2012, p. 180.

${ }^{14}$ Ibidem.

${ }^{15}$ BRITO, Angélica de. “A cruz vencerá o comunismo": o discurso anticomunista do jornal Folha Norte do Paraná (1962-1965). 152f. Programa de Pós Graduação em História, Universidade Estadual de

Maringá, Maringá, 2015, p.56. Disponível em: http://repositorio.uem.br:8080/jspui/bitstream/1/2952/1/000220421.pdf Acesso: 20/05/2020

${ }^{16}$ Ibidem. p. 21.
} 


\section{Sob a Influência Episcopal de Dom Jaime Luiz Coelho}

Não há como contar a história da Igreja Católica em Maringá de forma desconexa da história política, econômica e social da cidade; assim como, não há meios de refletir sobre esse contexto e não mencionar a figura de Dom Jaime Luiz Coelho.

A expansão do território paranaense com a abertura do Norte Central e Norte Novíssimo, já no século XX, desdobrou-se devido à política de concessões de terras públicas para empresas privadas: "a partir de 1916, várias glebas de terras foram concedidas para particulares, notadamente na região norte do Estado, mas principalmente na faixa quadrilátera formada pelos rios Paraná, Paranapanema, Tibagi e Ivaí. ${ }^{17}$

As geógrafas Cláudia Chies e Sandra Yokoo, complementam: "Desse modo, vale ressaltar que a colonização no norte paranaense ocorreu principalmente a partir da ação de algumas companhias colonizadoras, das quais se destaca a Companhia Melhoramentos Norte do Paraná". ${ }^{18}$

Priori, instrui que a Companhia Norte do Paraná - criada pela Holding Inglesa Paraná Plantation Limited, ficou responsável, a partir de 1929, pela colonização do Norte do Paraná. Mediante a política de vendas das terras, os territórios ao norte paranaense foram sendo ocupados por migrantes de outras regiões brasileiras, "colonos de procedências estrangeiras também se estabeleceram na região, muitos de forma espontânea, outros dirigidos por companhias". ${ }^{19}$

Desconsiderando as populações nativas, ou seja, nações indígenas e caboclos que habitavam a região, sob a propagação de um tal vazio demográfico, ${ }^{20}$ a colonização do Paraná prosseguia pelo século XX abrindo vilas, distritos e municípios. Não obstante, paróquias.

Nos anos 1940, quando uma civilização já se consolidava e os povoados se transformavam rapidamente em aglomerados

\footnotetext{
${ }^{17}$ PRIORI, Ângelo. O levante dos posseiros: a revolta camponesa de Porecatu e a ação do Partido Comunista Brasileiro no campo. Maringá: Eduem, 2011, p. 24.

${ }^{18}$ CHIES, Cláudia ; YOKOO, Sandra Carbonera. Colonização do Norte Paranaense: avanço da cafeicultura e problemas decorrentes deste processo. Rev. GEOMAE . Campo Mourão/PR. v.3 - n. 1.2012, pp.27 - 44. p.28 Disponível em: http://www.fecilcam.br/revista/index.php/geomae/article/view/204.\%20Acesso\%20 em\%2020/05/2020 Acesso em:20/05/2020

${ }^{19}$ PRIORI, O levante dos ... op. cit., p. 26-27.

${ }^{20}$ NOELLI, Francisco S.; MOTA, Lúcio T. A pré-história da Região onde se encontra Maringá, Paraná. In: Maringá e o Norte do Paraná. Estudos de história regional. DIAS, Reginaldo B.; GONÇALVES, José Henrique Rollo (org.). Maringá: EDUEM, 1999.
} 
urbanos, o governo passou a agir de maneira mais interessada. Ao simples anúncio de que uma cidadezinha começava a nascer - e isto acontecia com frequência surpreendente - a primeira coisa que fazia era instalar uma coletoria para garantir que todos pagassem seus tributos. Depois acionava a igreja para mandar logo um padre ao lugar. ${ }^{21}$

Não é necessário concordar efetivamente com Recco, a respeito do governo ser o responsável pela "vinda do padre", ou melhor, pela abertura das paróquias. A Igreja, como já mencionado, foi um agente ativo no processo civilizador nos moldes herdados pelo padroado; ${ }^{22}$ mas a citação ilustra o fato de que missionários e sacerdotes chegaram juntos ao que convencionou-se chamar de desenvolvimento.

Mediante tal conjuntura, Maringá em finais da década de 1940 estava na condição de distrito do município de Mandaguari, assim como a comunidade católica encontrava-se pertencente à Diocese de Jacarezinho, tendo por bispo Dom Geraldo de Proença Sigaud. Fundada em 1947, a cidade de Maringá foi emancipada somente em 1951: “A criação do município ocorreu através da lei 790/51, da Assembleia Legislativa do Estado, aprovada em 14 de novembro de 1951". ${ }^{23}$ O mesmo decreto criou também o município de Paranavaí. Em 1956 desmembra-se da Diocese de Jacarezinho e é criada a Diocese de Maringá.

"Uma Nova Igreja Para Um Jovem Bispo" - assim o padre Orivaldo Robles intitula o primeiro capítulo de sua obra publicada em $2007^{24}$ dedicado a Dom Jaime e a ereção da Diocese de Maringá. "Uma cidade nova, uma nova igreja e um jovem bispo" - parafraseando o padre Orivaldo (2007) - compuseram um novo panorama nos inícios do segundo meado do século XX, entabulando partes de uma mesma história: uma história social daquela que constituir-se-ia na mesorregião noroeste paranaense.

\footnotetext{
${ }^{21}$ RECCO, Rogério. Clareira Flamejante- O norte do Paraná antes e depois do advento da energia elétrica. Maringá: Gráfica e Editora Midiograf, 2007 45. Disponível em:https://www.yumpu.com/pt/document/ $\mathrm{read} / 63229706 /$ clareira-flamejante-o-norte-do-parana-antes-e-depois-do-advento-da-energia-eletrica Acesso 22/05/2020.

${ }^{22}$ Para pensar o Padroado Régio enquanto elemento estruturante da nação brasileira vale a pena conferir o artigo Padroado Régio no auge do império brasileiro, publicado por Patrícia Carla de Melo Martins. ANAIS DO III ENCONTRO NACIONAL DO GT HISTÓRIA DAS RELIGIÕES E DAS RELIGIOSIDADES - ANPUH -Questões teórico-metodológicas no estudo das religiões e religiosidades. IN: Revista Brasileira de História das Religiões. Maringá (PR) v. III, n.9, jan./2011. ISSN 1983-2859. Disponível em: http://www.dhi.uem.br/gtreligiao/pdf8/ ST6/014\%20\%20Patricia\%20Carla\%20de\%20Melo\%20Martins.pdf Acesso: 20/05/2020.

${ }^{23}$ FERREIRA, João Carlos Vicente. O Paraná e seus municípios. Cuiabá: J.C.V. Ferreira, 1999. p. 341.

${ }^{24}$ ROBLES, Orivaldo, Pe. A Igreja que brotou da mata. Maringá: PR: Dental Press, 2007.
} 
Quando em 1957 Dom Jaime assumiu o bispado, a Diocese de Maringá “possuía 450 mil habitantes divididos numa área de 14.902,67 Km²”25 . Em 1957 a região de Paranavaí contava com as paróquias: "Paranavaí, Alto Paraná, Nova Londrina, Loanda, Paraíso do Norte, Tamboara, Terra Rica e São João do Caiuá. Com a posse de Dom Jaime mais 07 paróquias foram criadas, conforme demonstra a tabela:

Tabela 01: Paróquias criadas na região de Paranavaí sob a administração de Dom Jaime Luiz Coelho

\begin{tabular}{c|c|c}
\hline Paróquia & Município & Data de Criação \\
\hline Santa Isabel Mãe do Precursor & Santa Isabel do Ivaí & $24 / 03 / 1959$ \\
\hline Nossa Senhora das Graças & Graciosa/Paranavaí & $09 / 08 / 1960$ \\
\hline Santa Terezinha do Menino Jesus & Planaltina do Paraná & $25 / 11 / 1960$ \\
\hline Santa Cruz do Monte Castelo & Santa Cruz do Monte Castelo & $12 / 12 / 1960$ \\
\hline Nossa Senhora das Dores & Paranavaí & $25 / 01 / 1964$ \\
\hline São Carlos Borromeu & São Carlos do Ivaí & $13 / 05 / 1964$ \\
\hline São Paulo Apóstolo & Querência do Norte & $15 / 08 / 1965$ \\
\hline
\end{tabular}

Observando a extensão das regiões norte central e noroeste (Norte Novíssimo), e o quanto o desenvolvimento sócio, político e econômico trilhou um caminho comum ao crescimento da comunidade católica, é possível dimensionar a importância de Dom Jaime na constituição histórica regional. Trata-se de histórias tão próximas que ao estudá-las não se sabe se a leitura é sobre a formação da Igreja em Maringá e região, ou sobre o processo de edificação da própria cidade e adjacências. Afinal, nas definições de Rosendhal:

É marcante a relação dialética entre a política da comunidade e a ordem religiosa. A comunidade religiosa constrói a Igreja e esta, na função político-social, sustenta a própria comunidade. Quer seja na ordem religiosa, quer pela ordem política, o território responde a duas funções. ${ }^{26}$

Embora considerado jovem para assumir o bispado, conforme ressalta padre Orivaldo: "com quarenta anos, seria um dos mais jovens membros

\footnotetext{
${ }^{25}$ GARUTI, Selson. O poder no anel na diocese de Maringá. Dissertação de mestrado, Pontíficia Universidade Católica de São Paulo S.P. 2006. f. 111. p.65. Disponível em: https://sapientia.pucsp.br/bitstream/handle/1977/1/SelsonGarutti.pdf. Acesso em 07/05/2020.
}

${ }^{26}$ ROSENDAHL, Território e...op. cit, p. 12930-12931. 
do episcopado brasileiro", ${ }^{27}$ o Monsenhor Jaime Luiz Coelho foi considerado meritório e apto a assumir o bispado. No dia 01 de fevereiro de 1956, o papa Pio XII cria as Dioceses de Londrina e Maringá, separando-as da Diocese de Jacarezinho por meio da Bula Latíssimas Partire Ecclesias.

Dom Jaime assumiu a Diocese de Maringá no dia 24 de março de 1957, função que ocupou até 1979, pois a Diocese de Maringá foi elevada a Arquidiocese em 16 de outubro de 1979. Enquanto bispo, Dom Jaime teve inúmeras participações em cargos eclesiásticos. Foi ele o primeiro Secretário Geral do Regional Sul II Paraná (1964-1965), além de Secretário Geral da Província Eclesiástica de Curitiba - PR (1957-1970). Foi membro da Comissão Representativa da CNBB, participação que durou de 1947 a 1978.

O papel de Dom Jaime na edificação sócio, política, econômica e religiosa do Norte e Norte Novíssimo do Paraná tem sido objeto de pesquisas da História Social e Religiosa. ${ }^{28}$ É fato que o bispo chegou na região quando esta expandia-se economicamente e as instituições estabeleciam-se. Sua influência não pode ser desprezada porque a hierarquia eclesiástica investiu Dom Jaime de um poder simbólico que ultrapassa a figura do religioso e o situa como uma liderança política. Entrementes, grande parte do poder que adquiriu Dom Jaime estava ligado ao papel religioso que desempenhava; era ele o detentor dos meios de salvação, ou seja, tinha o poder simbólico religioso na recém fundada diocese e território.

$\mathrm{O}$ avanço nas pesquisas com base na Geografia Cultural tem demonstrado que os símbolos sagrados - entre os quais a hierarquia de poderes - garante que o sistema religioso atribua sentido ao constructo social, colaborando com o formato civilizacional e territorial. A questão da pessoa do bispo como um agente social - empreendedor, inclusive - não é, necessariamente, inusitado. Rosendhal, esclarece com as seguintes palavras:

Essa questão envolve o conhecimento da religião como um sistema de símbolos sagrados e seus valores, envolvendo a produção, o consumo, o poder, as localizações e fluxos e os agentes sociais em suas dimensões econômica, política e do lugar. Portanto, o território está presente em todas estas dimensões. ${ }^{29}$

\footnotetext{
${ }^{27}$ ROBLES, op. cit. p. 26.

${ }^{28}$ GARUTTI, Selson. 0 poder no... op. cit.; PEREIRA, Márcia Maria. A Igreja Católica em Maringá e a gestão de D. Jaime Luiz Coelho (1947-1980). Dourados, MS: UFGD, 2007, f. 93.Disponível em: https://sapientia.pucsp.br/ bitstream/handle/1977/1/SelsonGarutti.pdf. Acesso em 07/05/2020.

${ }^{29}$ ROSENDAHL, 2005, p. 12929.
} 
O poder simbólico do bispo possibilitou-lhe introduzir-se no processo de construção social e, fato é, que a formação e sagacidade de Dom Jaime levou-o a fazer alianças promissoras e, sobretudo, a ter poder de direção sob os principais veículos de comunicação.

Nesta pesquisa não há intenção de optar por um viés ideológico, seja o defensor da construção da figura de Dom Jaime, seja o crítico em relação às posturas políticas defendidas pelo bispo. $O$ objetivo é contribuir com o entendimento qual o desenrolar histórico da sociedade e o estabelecimento da instituição católica na região pertenceram a um mesmo processo civilizador. E Dom Jaime foi agente de destaque desse processo.

\section{Dom Jaime e os Carmelitas em Paranavaí: Conflitos e avanços}

Quando Dom Jaime assumiu o bispado da Diocese de Maringá, Paranavaí e região estavam em pleno desenvolvimento econômico. Nas palavras de Silva: "Em 10 de outubro de 1956, Paranavaí foi considerado um dos cinco municípios de maior progresso do Brasil, diploma concedido à cidade por meio da Revista 0 Cruzeiro, do Rio de Janeiro". ${ }^{30}$

O desenvolvimento econômico engloba todo um contexto de desenvolvimento social, pois só ocorre desenvolvimento econômico na medida em que condições favoráveis reúnem crescimento demográfico, infraestrutura, instituições políticas, aparato jurídico, comércio, culturas e tantas outras contingências relacionadas ao processo civilizador. ${ }^{31}$

Tendo raízes principalmente na expansão cafeeira, a maneira como é formada as bases das sociedades ao Norte e Norte Novíssimo do Paraná explica costumes, conceitos, culturas próprias da região. Paulistas, mineiros, nordestinos, sulistas, europeus, asiáticos... Cristãos católicos, de outras denominações, e demais religiosidades. Um contingente humano mesclando crenças, conhecimentos e hábitos, a construir novos costumes em resposta a novas realidades. Hábitos e costumes que, enraizados no cotidiano, definem a cultura local. ${ }^{32}$

Não é um exercício custoso deslocar o pensamento para o cenário econômico e sociocultural da região na década de 1950, quando Frei Ulrico se torna pároco da Paróquia de Paranavaí. Porém, há um contraste entre o ideário

\footnotetext{
${ }^{30}$ SILVA, P. M. S. da. História de Paranavaí. Paranavaí: Fundo Municipal de Cultura, 2014, p.64.

${ }^{31}$ ELIAS, op. cit.

${ }^{32}$ THOMPSON, E. P. Costumes em comum. São Paulo: Companhia das Letras, 1998.
} 
de desenvolvimento e civilização e as impressões registradas por Frei Ulrico. Em agosto de 1951, chega a Paranavaí Frei Ulrico Goevert que, em setembro do mesmo ano, toma posse como vigário da Paróquia de São Sebastião. Eis como Frei Ulrico fala sobre sua chegada a Paranavaí:

Pouco depois de termos saído de Maringá, o quadro mudou completamente. Pela primeira vez a mata virgem do sul brasileiro. Enormes superfícies foram desmatadas nas semanas anteriores, pois o final de agosto e começo de setembro é o chamado 'tempo das queimadas'. Em monstruosas colunas, subia a fumaça céu acima e cobria o sol. Como um prato muito avermelhado estava o sol no horizonte. Uma cinza branca caía suavemente no solo. A cinza parecia como neve suja. As superfícies queimadas causavam uma desoladora impressão! Enormes árvores deitadas como corpos mortos no solo e, ao lado, arbustos meio queimados, estendiam seus poucos galhos nus, como que suplicando aos céus ajuda. 0 provincial leu aparentemente meus pensamentos e polidamente disse: 'O senhor deverá se acostumar com este triste aspecto. ${ }^{33}$

O ideário de desenvolvimento e civilização da região fundamenta-se a partir da criação do Distrito de Montoya, em 13 de abril de 1929 - comportava a Fazenda Ivaí -, embrião de Paranavaí, que tornar-se-ia município em 1951. ${ }^{34}$ Entretanto, a história local não é feita somente de ideais de colonização, construções de estradas, plantio cafeeiro e colheitas abundantes. Contando a história de Paranavaí, Silva ${ }^{35}$ narra a saga dos nordestinos e demais migrantes que, envolvidos no processo de construção da sociedade paranavaiense, sofreram as consequências da luta entre os grupos que disputavam a posse da terra e o poder local.

Assim sendo, sobre o território tomado dos povos originários ergueu-se uma sociedade fincada na luta pela posse da terra e hegemonia política. Frei Ulrico deparou-se não somente com a paisagem de mata virgem sendo devastada pelas queimadas. Encontrou um povo que se enredava, entre a miscelânea de culturas distintas, uns à prosperidade e outros à sobrevivência. Cenário propício para quem saiu de sua terra natal disposto a fazer missão:

\footnotetext{
${ }^{33}$ GOEVERT, Frei Ulrico. História e memórias de Paranavaí. Trad. e notas Frei Wilmar Santin, o Carm. Paranavaí: Livraria Nossa Senhora do Carmo, [1957]1992.

${ }^{34}$ SILVA, P. M. S. da. História de Paranavaí. $2^{\mathrm{a}}$ ed. Fundo Municipal de Cultura. Paranavaí, 2014. ${ }^{35}$ Ibidem.
} 
construir a Igreja de Cristo nos confins da América do Sul. ${ }^{36}$ Literalmente a igreja estava por ser construída:

Pedi ao provincial para primeiramente me levar à igreja. Sem me dar resposta, parou diante de uma casa de madeira, sem telhado e com pequena torre: 'Esta é a igreja. Ela deve ser novamente coberta e aumentada. Este deverá ser o seu primeiro trabalho. Há ainda um pouco de dinheiro de uma festa que o povo fez. ${ }^{37}$

Frei Ulrico Goevert discorre sobre as mazelas do povo argumentando sobre a necessidade de se trabalhar arduamente para que a moral católica seja implantada:

"Agora quero contar algo sobre as pessoas que chegam aqui, nestes lugares novos, para colonizar a terra. Muitas vezes são refugiados de outros estados ou países, que querem construir uma nova vida. Por isso temos também uma mistura internacional aqui reunida". ${ }^{38}$

Os relatos de Frei Ulrico e outros freis oportunizam pensar a paisagem, os limites daquela gente, o contexto social e os avanços obtidos quando da chegada dos freis carmelitas à região do Norte Novíssimo, a partir da década de 1950. Não se pode negar que exerceram grande influência, não somente na formação religiosa, mas, efetivamente, na formação sociocultural da região.

A paróquia designada por Dom Sigaud aos freis carmelitas crescia na intensidade que Paranavaí progredia: "A cidade de Paranavaí - pode-se dizer sem exagero - crescia diariamente. Também nas redondezas a população crescia continuamente". ${ }^{39}$ E Frei Ulrico desenvolveu métodos próprios para alcançar a multidão com ensinamentos catequéticos, mas também contribuindo com a formação educacional:

Não dava para simplesmente resolver o problema com aulas de religião nas escolas, pois escolas como tal era algo muito raro nos primeiros anos. Escolas públicas simplesmente não havia. Para resolver a situação Frei Ulrico fundou uma escola paroquial. ${ }^{40}$

\footnotetext{
${ }^{36} \mathrm{KNOBLAUCH}$, Frei Joaquim. Os vinte cinco anos dos carmelitas da Província Germaniae Superioris no Brasil. Trad. Frei Wilmar Santin, 1976.

${ }^{37}$ GOEVERT, op. cit. 08.

${ }^{38}$ Ibidem, p. 09.

${ }^{39}$ KNOBLAUCH, op. cit. p. 12.

${ }^{40}$ Ibidem. pp. 9-10.
} 
Empenhados pela missão, os freis carmelitas estiveram, senão à frente, ao menos ao lado, inseridos no processo de edificação das sociedades que se formaram ao entorno da Paróquia de Paranavaí. Rezando missas, realizando sacramentos, construindo igrejas e escolas, seminário e convento, indo ao encontro das necessidades da população em formação. Portanto, é natural que os freis almejassem perpetuar a autonomia que tinham na região sob o pastoreio de Dom Sigaud, bispo da Diocese de Jacarezinho. No entanto, a resolução de desmembrar a Paróquia de Paranavaí da Diocese de Jacarezinho, e submetê-la à Diocese de Maringá, resultou num conflito de duas vias: Dom Jaime não se sentiu acolhido pelos freis carmelitas e, estes, estranharam o bispo. Frei Joaquim Knoblauch, afirma que "O bispo de Maringá não era nada favorável (simpático) aos religiosos". ${ }^{41}$

O padre Orivaldo Robles ${ }^{42}$ esclarece que os freis alemães acostumados a ter autonomia na região de Paranavaí sob o bispado de Dom Sigaud, até mesmo pela distância entre Paranavaí e Jacarezinho, entenderam que "a proximidade com o bispo certamente faria mudar. Por isso, a criação do bispado de Maringá não lhes trouxe especial contentamento". ${ }^{43}$

Dom Jaime sentia-se incomodado, reclamava até mesmo dos freis conversarem em alemão na sua presença, já que ele não dominava a língua. "Os frades, com frequência, conversavam em alemão num desejo, quem sabe, de esconder ao bispo algum assunto ou comentário". ${ }^{44}$

Os freis carmelitas se sentiam incomodados com a presença do superior. Ao utilizarem a prática da barreira linguística será que intencionavam esconder algo de Dom Jaime, ou, talvez, pontuar a distância entre eles e o bispo? Dom Jaime administrava a diocese, as paróquias, tomava decisões, mas não podia entender o que os freis falavam. Essa prática pode ser pensada como uma tática que os freis utilizaram para burlar o autoritarismo do bispo.

\section{O lema de Dom Jaime: In Omnibus Christus. Ou In Omnibus Pecuniae.}

$\mathrm{O}$ artigo do Pe. Marcos Roberto ${ }^{45}$ aponta o bispo como um personagem que lutou arduamente para a projeção do catolicismo na Diocese de Maringá,

\footnotetext{
${ }^{41}$ Ibidem, p. 5.

${ }^{42}$ ROBLES, op. cit.

${ }^{43}$ Ibidem, p. 42.

${ }^{44}$ DIOCESE DE MARINGÁ, 1957ª , f.68 apud ROBLES, 2007, pp. 42-43.

${ }^{45}$ SANTOS, Pe. Marcos Roberto Almeida dos. “Artigo de padre Marcos Roberto: Cem anos de dom Jaime-O centenário de um paulista”. Cúria Metropolitana de Maringá, 2016, Maringá. Disponível em: http://arquidiocesedemaringa.org.br/noticias/704/artigo-de-padre-marcos-roberto-cem-anos-de-dom-jaime-o-centenario-de-um-paulista Acesso em: 05/05/2020.
} 
e o apresenta como um grande articulador, pois lograva sucesso nos mais variados espaços. A historiografia reproduzida por Pe. Marcos Roberto qualifica Dom Jaime como um grande empreendedor.

Empreendedorismo e persuasão são traços atribuídos à personalidade de Dom Jaime. O bispo tinha a missão de estruturar a Diocese de Maringá e manter a Igreja Católica como força motriz dessa sociedade, para tanto ele precisava convencer as pessoas que o seu projeto, ou seja, sua proposta era relevante.

Frei Alberto, em relação à figura de Dom Jaime, expõe: "Nas reuniões do clero só se falava em dinheiro, taxas, contribuições e percentagens que deviam ser enviadas para a cúria. O lema de Dom Jaime era: IN OMNIBUS CHRISTUS (Em tudo Cristo). Nós mudamos um pouco para: in omnibus pecuniae (Em tudo dinheiro)." ${ }^{46}$

A historiografia tem associado a pessoa de Dom Jaime à edificação e progresso da sociedade Norte do Paraná, afinal, a consolidação sociopolítica e o crescimento econômico da região coincidem com a vinda e presença do bispo. Mas, não deixa de ser realidade que o contexto histórico valia-se da expansão social como modelo implementado pela ordem econômica vigente naquele momento, conforme Nicolau Sevcenko, sintetiza: ${ }^{47}$

O salto direto de uma população majoritariamente analfabeta no início do século para uma ordem cultural centrada nos estímulos sensoriais das imagens e dos sons tecnicamente ampliados, fornece uma indicação da trajetória da sociedade brasileira nesse período de mudanças intensas e rápidas. Expostas de um lado às pressões de um mercado intrusivo e de outro às intervenções das elites dirigentes, empenhadas em modelar as formas e expressões da vida social, as pessoas e grupos se viram forçados a mudar, ajustar e reajustar seus modos de vida, ideias e valores sucessivas vezes. ${ }^{48}$

Não obstante às transformações que o país vivenciava, a Igreja Católica remodelava seus próprios direcionamentos. Portanto, Dom Jaime em seus primeiros anos de bispado passa pelo período de transformação nos direcionamentos da Igreja Católica. Em 1958, morre o papa Pio XII e o Sumo Pontífice passa a ser João XXIII. Este papa leva a Igreja, de maneira geral, a repensar seu papel na sociedade.

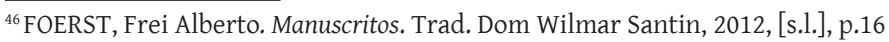

${ }^{47}$ SEVCENKO, N. (Org.) O Prelúdio Republicano, Astúcias da Ordem e Ilusões do Progresso. In: NOVAIS, F. A. (coord.). História da Vida Privada no Brasil. Vol. 3. São Paulo: Companhia das Letras, 1998, pp. 7-48.

${ }^{48}$ Ibidem, p. 38.
} 
Em abril de 1962 foi aprovado o "Plano de Emergência para a Igreja do Brasil", ${ }^{49}$ e em outubro de 1962 inicia-se o Concílio Vaticano II. Todos esses fatores vão influenciar nas ações e decisões de Dom Jaime. Segundo Garutti:

A Arquidiocese de Maringá procurou desenvolver um projeto evangelizador sintonizando a sua ação pastoral com uma noção cultural delineada pelo então Bispo Dom Jaime Luiz Coelho, estando em conformidade tanto com a Conferência nacional dos Bispos do Brasil (CNBB), quanto com a Igreja do Paraná (regional Sul II). ${ }^{50}$

\section{Ainda segundo Garutti:}

Entre os Planos Pastorais implantados na Diocese de Maringá pode-se citar: 1973 - 1ํo Plano de Ação Pastoral; “Implantação do Plano orgânico da Diocese"; 1974 - 2º Plano de Ação Pastoral: "A face da Igreja peregrina"; 1975 - 3ํ Plano de Ação Pastoral: "Ano santo e Ano Eucarístico no Brasil”; 1976 - 4º Plano de Ação Pastoral: "Diretrizes da ação Pastoral da Igreja no Brasil" (CNBB) - enfoque na CEBs e Pastoral da Família; 1977 - 5ํ Plano de Ação Pastoral: "Vem Senhor Jesus"; 1978/79 - 60 Plano de Ação Pastoral: "Evangelii Nuntiandi”; 1980/81 - 7º Plano de Ação Pastoral: "Na década de Puebla"; 1981 - 8ํ Plano de Ação Pastoral: "Ano Jubilar"; 1982 - 9o Plano de Ação Pastoral: "Caminhada de 25 anos"; 1983 - 10ํ Plano de Ação Pastoral: "Catequese Renovada"; 1984 - 11ํ Plano de Ação Pastoral "Para continuar o serviço de evangelização"; 1985 - 12º Plano de Ação Pastoral: "Lutamos porque cremos - ano Internacional da Juventude". 1986 - 13ํ Plano de Ação Pastoral: “Tornar a terra de Deus e de

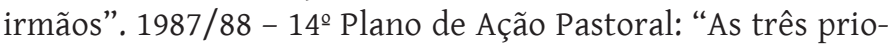
ridades Pastorais do Regional Sul II”; 1989/92 - 15 Plano de

${ }^{49} \mathrm{O}$ episcopado brasileiro pretendia“"...] realizar no Brasil uma presença vital da Igreja, que salvará as almas e salvará a Nação de todas as ameaças que, contra ela, se levantam: como o comunismo ateu e demolidor dos valores mais autênticos do homem; as concepções destruidoras da dignidade da família e as reiteradas tentativas divorcistas com as quais jamais se poderá conformar a consciência dos eleitores cristãos; a mentalidade laicizante que teima em voltar ao cenário do País, ao menos em alguns setores de suas atividades; o egoísmo e o lucro erigidos pelo liberalismo econômico em suprema norma a governar as atividades produtoras da Nação e que devem cristãmente dar lugar ao espírito de serviço e de bem comum, se não quisermos ver os desequilíbrios sociais crescerem até o desespero".(CNBB. Plano de Emergência para a Igreja do Brasil". Caderno № 1, 1963. São Paulo: Paulinas, 2004, p.15. Disponível em:http://portal. pucminas.br/imagedb/documento/DOC_DSC_NOME_ARQUI20130906183649.pdf. Acesso em 21/08/2020.

${ }^{50} \mathrm{GARUTTI}$, Selson. A constituição histórica da formação do catolicismo pioneiro em Maringá. Anais do II Encontro Nacional do GT História das Religiões e Religiosidades. Revista Brasileira das Religiões-ANPUH. Maringá-PR. V. 1, n. 3, 2009. ISSN 1983-2859. p. 15. Disponível em: http://www.dhi.uem.br/gtreligiao/rbhr/a_constituicao_historica_da_formacao_do_catolicismo1.pdf·Acesso em: 23/08/2020. 
Ação Pastoral: "Assumir as seis linhas da Ação Pastoral e os seus Destaques Pastorais. ${ }^{51}$

Esses documentos pontuados por Garutti, corroboram o ajustamento da ação pastoral sob a liderança de Dom Jaime aos direcionamentos do episcopado brasileiro. Contanto, a atuação do Bispo deu-se num momento em que a expansão econômica e social determinava o processo civilizador da região, mediante o contingente advindo com a abertura do Norte Novíssimo.

Este texto tem se inclinado a perceber não a pessoa de Dom Jaime como o grande empreendedor da região Norte do Paraná, conforme a historiografia local anui. E sim entender o processo civilizador ensejado na região para o qual a Igreja destinou seu projeto e, categoricamente, Dom Jaime correspondeu. Mesmo porque, a autoridade exercida por Dom Jaime advinha do poder simbólico que a Igreja lhe garantia.

No livro de tombo da Paróquia São Sebastião registrou-se os inúmeros pedidos de Dom Jaime em relação a questões econômicas. O que mais chama a atenção são os vários pedidos para a construção do Seminário Diocesano, espórtulas, porcentagens que os padres seculares e regulares deveriam retirar das festas comuns ou especiais, entre outros.

O livro de tombo traz importantes informações acerca do contexto histórico-social, religioso e até econômico da época estudada, no entanto, trabalhar com livro de tombo é uma tarefa que exige "conhecimento das letras em todas as suas modalidades (assentada, cursiva, cortesã, processada), e também abreviaturas, sinais gráficos, acentuação, numerais e sinais criptográficos (escrita cifrada)". ${ }^{52}$ Além do exposto, é importante levar em consideração que esse documento foi produzido para registrar a história de determinada paróquia e como tal, o documento deveria atender aos interesses daquela instituição.

Um outro ponto significativo ao utilizar o livro de tombo como fonte diz respeito a dificuldade de acesso, pois alguns bispos "interpõem dificuldades quase intransponíveis, enquanto outros são bastante liberais e abrem

\footnotetext{
${ }^{51}$ Ibidem, p. 15.

${ }^{52}$ PEDRAS, Beatriz Junqueira. Uma leitura do I Livro de Tombo do Convento do Carmo em Salvador: contribuição à construção histórica da Ordem dos Carmelitas na Bahia Colonial. Dissertação de mestrado. Escola de Ciência da Informação, Belo Horizonte-MG, 2000, p.44. Disponível em: https://repositorio.ufmg.br/ bitstream/1843/LHLS-69URYB/1/mestrado__beatriz_junqueira_pedras.pdf. Acesso em: 23/08/2020.
} 
até mesmo documentação mais sensível, como os processos relativos aos próprios religiosos". ${ }^{33}$

O primeiro registro de Dom Jaime no livro de tombo da Paróquia São Sebastião é uma crítica a obrigação do vigário em realizar os registros paroquiais. Esse documento que era utilizado para controlar o que ocorria nas paróquias e nas capelas, também era um documento que orientava o bispo acerca dos grupos católicos. Em relação ao preenchimento do livro de tombo executado pelos carmelitas, Dom Jaime reclama:

Quando, em setembro do ano passado, por ocasião da minha primeira visita oficial à Paróquia propositalmente, não pedi os livros do arquivo, para examiná-los, dando tempo ao Vigário para que os deixasse em ordem. Agora, porém, não posso aprovar esta atitude $[\ldots] . .^{54}$

A citação é de 15 de junho de 1958. Frei Ulrico começa a colocar em ordem o livro. Na folha seguinte o frei narra o processo de desmembramento da Diocese de Jacarezinho e ereção das Dioceses de Maringá e Londrina. Outro ponto que ele aborda são as três reuniões do clero diocesano de Maringá realizadas por Dom Jaime no ano de 1957: 30 de abril, 03 de setembro e 30 de novembro.

Na primeira reunião realizada não há informações acerca das recomendações realizadas por Dom Jaime. Na descrição, Frei Ulrico coloca que Dom Jaime marcou uma visita oficial com crisma do dia 21 de setembro a 02 de outubro. Para a visita de Dom Jaime foram mobilizadas as pessoas que dispunham de carro, autoridades estaduais, municipais e federais. Também foram mobilizados os civis e militares, e alunos da Escola Paroquial. Ou seja, foi organizado um evento municipal para recepcionar o bispo. No decorrer desses dias de Visita Pastoral, Dom Jaime crismou 5.000 pessoas. No entanto, chamo a atenção para a frase "nesta mesma reunião recebi também a licença para os padres capuchinhos pregar missão na freguesia de Paranavaí." ${ }^{55}$ Segundo Frei Ulrico: "Mais um movimento de grande envergadura na vida religiosa da Paróquia de Paranavaí, as missões pregadas pelos Padres Capuchinhos do dia 7 até dia 16 de julho de $1957 "{ }^{56}$

\footnotetext{
${ }^{53}$ BACELLAR, Carlos. Fontes documentais: uso e mau uso dos arquivos. IN; PINSKY, Carla Bassanezi (org.). Fontes Históricas. $2^{\mathrm{a}}$ ed. São Paulo: Contexto, 2008. p.40.

${ }^{54}$ ARQUIVO SANTUÁRIO DO CARMO. Livro de tombo da paróquia São Sebastião, 1958, Paranavaí , p.21.

${ }^{55}$ Ibidem, p.22

${ }^{56}$ Ibidem, p. 21
} 
O livro de tombo da Paróquia de São Sebastião faz referência às Santas Missões da Igreja Católica. Fato é que, mediante as missões, ocorreu a queima de livros considerados inapropriados para católicos. Tal situação remete ao período em que a Igreja Católica exercia supremacia e fazia uso do Index para direcionar a leitura dos católicos. Elementos simbólicos intercruzam-se na ocorrência: a intervenção da igreja na formação das pessoas, o uso do fogo para simbolizar a purificação, pois ao queimar os livros que não deveriam ser lidos, queima-se também a antiga crença desvirtuada ou herética: "No fim das Santas Missões os padres capuchinhos fizeram uma grande fogueira na qual queimaram os livros protestantes que os fiéis quase sempre por ignorância tinham lido[...]". ${ }^{57}$

No momento de estruturação da Igreja Católica na região de Paranavaí, o desconhecimento da maioria dos leigos frente aos preceitos católicos era algo que incomodava os freis carmelitas e foi retratado em várias narrativas. A queima dos livros não condizentes com a doutrina católica pressupunha uma maneira de controlar as expressões populares e aqueles que, porventura, se desviaram do caminho da salvação considerado correto pela instituição. Nisso consiste que a normatização dos padrões de comportamento segue a lógica do controle social, com base na doutrina religiosa.

$\mathrm{Na}$ visão dos freis carmelitas o catolicismo que se desenvolvia na região missionária de Paranavaí estava permeado de ignorância e crendices desnecessárias. Grande porcentagem da população era analfabeta. As práticas culturais e econômicas do povo estavam ligadas ao ambiente rural. A relação das comunidades com o sagrado estava determinada pelo contexto local e a vivência religiosa baseada na tradição das festas, ritos e símbolos, com destaque para a devoção aos santos.

\section{O Poder Simbólico: Dom Jaime e os Carmelitas no Campo das Trocas}

Pensar o processo civilizador em Paranavaí e região nos meados do século XX, indispensavelmente, remonta pensar as relações estabelecidas pelos freis carmelitas da Província de Bamberg e os bispos das duas dioceses que gestaram a Diocese de Paranavaí. ${ }^{58}$

\footnotetext{
${ }^{57}$ Ibidem, p .23

${ }^{58}$ Dom Geraldo de Proença Sigaud, bispo da Diocese de Jacarezinho (1947-1961). Dom Jaime Luiz Coelho, bispo da Diocese de Maringá (1957-1979).
} 
Se o relacionamento dos freis com Dom Sigaud, por identidade ideológica, ou distância espacial, não apresentou conflitos, com Dom Jaime não se pode inferir o mesmo. As fontes analisadas apresentam um ou outro queixume, de ambas as partes, embora velados.

Dom Jaime ao assumir a Diocese de Maringá, e receber o Norte Novíssimo como herança da Diocese de Jacarezinho, adentrou o campo onde os freis carmelitas já haviam semeado sementes do poder simbólico inerente à liderança religiosa. Ao passo que, os freis carmelitas ao receberem Dom Jaime como sucessor de Dom Sigaud, foram submetidos, mediante a economia das trocas simbólicas, à autoridade de um que lhes era estranho. Estranha cumplicidade, a de impulsionar um mesmo processo conservando a disputa pelo poder sem, objetivamente, expor as fissuras. Bourdieu explica:

[...] o poder[...] é necessário saber descobri-lo onde ele se deixa ver menos, onde ele é mais completamente ignorado, portanto, reconhecido o poder simbólico é, com efeito, esse poder invisível o qual só pode ser exercido com a cumplicidade daqueles que não querem saber que lhe estão sujeitos ou mesmo que o exercem. ${ }^{59}$

Que Dom Jaime traçasse os caminhos de sua diocese, e que os religiosos carmelitas se sentissem titulares das comunidades católicas formadas em sua região missionária, é fato que não causa espanto. A relação que se estabeleceu naturalmente entre as duas forças, conforme pode ser entendido com base na divisão do trabalho religioso em face das estruturas sociais, expressa muito mais a legitimação política dos agentes do capital religioso do que picuinhas entre bispo e religiosos.

Em função de sua posição na estrutura da distribuição do capital de autoridade propriamente religiosa, as diferentes instâncias religiosas, indivíduos ou instituições, podem lançar mão do capital religioso, na concorrência pelo monopólio da gestão dos bens de salvação [...]. ${ }^{60}$

Um episódio pode ser elencado como demonstração da disputa política pelo capital religioso entre os freis e o bispo. Frei Alberto Foerst,${ }^{61}$ comenta a

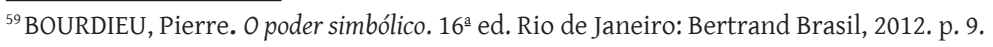

${ }^{60} \mathrm{Ibidem}, \mathrm{p} .57$.

${ }^{61}$ Frei Dom Alberto Foerst, ou melhor, Johann Foerst nasceu dia 26/11/1926 em Gunzendorf - Alemanha. Em 1944 foi chamado a ser soldado na $2^{\mathrm{a}}$ Guerra Mundial. Durante 8 meses foi prisioneiro de guerra dos americanos na França. Em 1946 retornou ao seminário. Fez o noviciado em 1947 na cidade de Straubing. Foi ordenado em 29/06/52. Após sua ordenação trabalhou em Beilstein e Springiersbach e no Marianum.
} 
respeito de um grupo de 4 freiras carmelitas que chegaram a Paranavaí, em junho de 1955, para auxiliar os missionários carmelitas alemães. Nas entrelinhas, a narrativa reconhece que Dom Jaime desdenhou da presença das irmãs, requerendo os espaços ocupados por elas, não somente uma, mas duas vezes deslocando as irmãs e enviando irmãs Vicentinas para ocupar as funções. ${ }^{62}$

No processo de criação de novas paróquias, Dom Jaime vai (re) afirmando sua influência e impondo seu poder. E no contexto, sendo o bispo o expoente máximo da gestão dos bens de salvação, prevalece sua autoridade ao requerer uma propriedade angariada pelos carmelitas, e instalar lá uma congregação feminina indicada por ele.

No dia 25 de fevereiro de 1959, em uma audiência o "Sr. Bispo pediu mais uma vez a entrega do Jardim da Infância e das três datas para a construção de um colégio feminino, efetivamente entregou-se está propriedade a Mitra Diocesana". ${ }^{63}$ Ainda em relação a doação dessas propriedades, Dom Jaime, em visita Pastoral realizada em 20 de abril de 1959, declara:

Os termos anunciado, no dia da abertura da Visita Pastoral, a vinda de Religiosas, no próximo ano para dirigirem um Colégio para meninas, pudemos constatar a alegria de todos. Trabalhem pois, os Revmos. Ser. Padres, com os membros da Comissão da igreja, para a urgente e adequada preparação da residência das Irmãs, que se instalarão no atual prédio do Jardim de Infância, ora de propriedade da Mitra Diocesana, cedido pela ordem dos Padres Carmelitas, e assim o Colégio será, em breve, uma realidade. ${ }^{64}$

Problematizar os interesses que nortearam as ações dos agentes do capital religioso é imprescindível para entender a estruturação da igreja católica, em Paranavaí e região, em meio ao processo civilizador. É necessário pensar as motivações que levaram Dom Jaime a optar pelas irmãs Vicentinas, ou melhor, por que a aliança com as Irmãs Vicentinas atraía Dom Jaime em detrimento às Irmãs Carmelitas? Não cabe aqui dar respostas imediatistas.

\footnotetext{
Em 1953 foi transferido para Fürth e no ano seguinte foi enviado ao Brasil. Em 1985 Dom Alberto foi transferido para Dourados, Mato Grosso do Sul. Na paróquia Bom Jesus terminou o centro catequético, reformou e ampliou a igreja e a casa paroquial. Construiu o salão paroquial. Em 1986 foi nomeado vigário geral. Como tal reformou a catedral, sugeriu e projetou o IPAD (Instituto Diocesano de Pastoral). Em 06 de julho de 1988 foi nomeado bispo e ordenado bispo coadjutor de Dourados em 07 de setembro do mesmo ano. FOERST, Alberto, et al. As aventuras de 3 missionários alemães em Paranavaí. Trad. e notas Frei Wilmar Santin. Paranavaí, 2001, p.94-96. Disponível em: http://ocarmelo.blogspot.com.br/ Acesso em: 20/08/ 2020. p.94.

${ }^{62}$ FOERST, Frei Alberto. Manuscritos. Trad. Dom Wilmar Santin, 2012, [s.l.], p.12

${ }^{63}$ ARQUIVO SANTUÁRIO DO CARMO. Livro de tombo da paróquia São Sebastião, 1959, p. 29

${ }^{64}$ Ibidem, p. 30.
} 
O interesse, a princípio, é refletir sobre a situação, já que o processo que constituiu a história religiosa de Paranavaí foi permeado pelas várias ações delineadas por seus agentes históricos. E nesse contexto, Dom Jaime, ao que tudo indica, tentava minimizar a influência que os freis carmelitas tinham ou poderiam vir a ter em Paranavaí.

Disputa política no campo das trocas dos bens de salvação? Correlação de forças entre poderes simbólicos? A veleidade das queixas entre as partes indica parcimônia ou a violência - camuflada - dos interesses pelo controle da região? Bourdieu, oportuniza pensar o poder simbólico como mecanismos no jogo de dominação: "O poder simbólico, poder subordinado, é uma forma transformada, quer dizer, irreconhecível, transfigurada e legitimada, das outras formas de poder[...]". ${ }^{65}$

Outra situação na qual o bispo de Maringá confrontou o poder simbólico da comunidade carmelita ocorreu quando um jovem teuto- catarinense, que tinha o objetivo de ser carmelita, foi persuadido por Dom Jaime a mudar de campo. Foerst, narra que Frei Bernardo, após fazer o noviciado na Alemanha, adoeceu de câncer, e faleceu 5 anos depois. Porém, o queixume de Foerst é pelo fato de Dom Jaime ter atraído o jovem para si, conforme descreve:

Acontece que o padre já não mais estava conosco porque Dom Jaime Luiz de Maringá o convidou pra entrar na sua Diocese. 0 religioso não resistiu a este convite e foi nomeado vigário de Santa Isabel do Ivaí. Não demorou até que a morte o alcançou. Ele está enterrado na igreja de Santa Isabel do Ivaí. ${ }^{66}$

Frei Bernardo Rech era filho de teuto-catarinenses que viviam em Graciosa, uma comunidade pela qual os freis carmelitas nutriam especial predileção. Bernardo Rech foi ordenado padre em 18 de dezembro de 1955, e como ele queria ser carmelita, foi enviado em 1956 para fazer noviciado em Straubing ${ }^{67}$, onde realizou os votos simples. ${ }^{68}$

A carência de vocacionados para exercerem o trabalho religioso na região é menção recorrente nos registros carmelitas. O fato é que Frei Foerst registra não somente o trágico destino de Rech, mas a mudança em sua trajetória religiosa, acentuando a influência de Dom Jaime. E por que Dom

\footnotetext{
${ }^{65}$ BOURDIEU, op. cit., p. 19.

${ }^{66}$ FOERST, op cit. p. 20.

${ }^{67}$ Straubing é um município do estado da Baviera, Alemanha.

${ }^{68}$ KNOBLAUCH, op. cit. p. 12.
} 
Jaime escolhera e cooptara o jovem religioso para os serviços diocesanos? Demonstração de autoridade? Afeto? Ou estratégia para ampliar seu campo de poder?

\section{A Ereção da Diocese de Paranavaí: Fronteiras Sucessivas na Estratégia de Dom Jaime}

A Diocese de Paranavaí foi criada em 20 de janeiro de 1968, sua instalação ocorreu no dia 07 de julho de 1968. Essa diocese foi erigida em uma parcela da última área da ocupação e consequente colonização do Paraná denominada Norte Novíssimo ${ }^{69}$.

Fundar uma nova sede de um bispado no Norte Novíssimo era importante para que a Igreja se tornasse uma força atuante naquele território. A cidade de Paranavaí, além de ser um pequeno polo da região conhecida como Norte Novíssimo, apresentava uma localização estratégica. Paranavaí dista de Maringá apenas $80 \mathrm{~km}$. O ponto mais distante em relação a futura sede da diocese estaria a $130 \mathrm{~km}$, a paróquia de São Paulo Apóstolo de Querência do Norte. Dentre as cidades do noroeste do Paraná, Paranavaí reunia as melhores características para ser sede do novo bispado na região.

A região de Paranavaí, em razão do tardio processo de ocupação ${ }^{70}$, e por causa do crescimento econômico com base na lavoura de café, atraiu um contingente populacional provindo de outras regiões brasileiras, como por exemplo, Pernambuco e Ceará, Santa Catarina, Rio Grande do Sul e São Paulo. Também foi nesse período que a imigração alemã, japonesa, italiana,

\footnotetext{
${ }^{69}$ A região denominada Norte Novíssimo do estado do Paraná é agrupada em três microrregiões: Cianorte, Paranavaí e Umuarama. Atualmente essa região é conhecida como noroeste do Paraná.

${ }^{70}$ O Norte Novíssimo desenvolve-se a partir do século XX. Portanto, considerado tardio em relação ao histórico de ocupação dos territórios paranaenses. Para aprofundar a história da ocupação do Paraná indico BALHANA; MACHADO; WESTPHALEN. História Do Paraná. Curitiba: GRAFIPAR, 1969; REBECCHI, Murilo. Entre a colonização do noroeste do Paraná e a preservação da memória de um povo esquecido: os Xetá. Programa de Pós Graduação em História da Universidade Estadual de Maringá, Maringá, 2014.f. 97; ALCANTARA, José Carlos. Política Local: um estudo de caso (Paranavaí: 1952-1982). Campinas, 1987. Dissertação (Mestrado em Ciências Sociais). Universidade Estadual de Campinas. Disponível em: http://repositorio.unicamp.br/ jspui/bitstream/REPOSIP/281897/1/Alcantara_JoseCarlos_M.pdf:Acesso em:10/05/2020; MARTINS. Gelise Cristine Ponce Martins. As relações cotidianas de uma comunidade de cafeicultores, nas memórias de Braz Ponce Martins (1897-1975) Programa de Pós-Graduação em História, área de concentração: Política, Movimentos Populacionais e Sociais, da Universidade Estadual de Maringá, Maringá-PR, 2012, f.230; SILVA, P. M. S. da. História de Paranavaí. Edição Comemorativa aos 36 anos de Paranavaí. Obra Destinada ao Patrimônio Histórico-Cultural de Paranavaí. Paranavaí: [s.e.] 1987; WACHOWICZ, Ruy. História do Paraná. Curitiba: Imprensa Oficial do Paraná, 2001.
} 
libanesa, turca, espanhola e árabe aportou na região, para trabalhar nas mais variadas profissões. ${ }^{71}$

Isso quer dizer que a região confluiu um contingente humano diverso em culturas, costumes, inclusive, maneiras de vivenciar a fé católica. Não obstante, a Igreja Católica, no período, seguia uma orientação vinculada ao movimento ultramontano, ou seja, prezava pelo conservadorismo e as tradições romanizadas: "Em uma definição bastante esquemática, entende-se por catolicismo romanizado ou ultramontano aquele catolicismo praticado entre 1800 e 1960, nos pontificados de Pio VII a Pio XII [...]". ${ }^{72}$

Por esse viés, identifica-se que a criação da Diocese de Paranavaí, com a introdução de um bispo presente no cotidiano da comunidade, atendia ao conceito certeauniano de estratégia da instituição em contrapartida às práticas do cotidiano: "Como na administração de empresas, toda racionalização 'estratégica' procura em primeiro lugar distinguir de um 'ambiente' um 'próprio', isto é, um lugar do poder e do querer próprios". ${ }^{73}$

Para Marinho ${ }^{74}$ foi o desenvolvimento da região noroeste que fez com que a Província Eclesiástica do Paraná sentisse a necessidade da criação de um novo bispado em Paranavaí. Essa ideia passou a ser discutida já a partir do início da década de 1960. A primeira providência foi a criação de uma segunda paróquia na cidade - "o que logo ocorreu, através do Decreto datado de 25 de janeiro de 1964, quando Dom Jaime Luiz Coelho, Bispo Diocesano de Maringá, criou a Paróquia de Nossa Senhora das Dores, instalada no dia 02 de fevereiro, do mesmo ano". ${ }^{75}$ Dessa maneira, a primeira ação de Dom Jaime em busca de concretizar o projeto de criação de uma nova diocese, foi fundar a Paróquia Nossa Senhora das Dores que ficou a cargo do padre Eugênio Nichele.

Quanto aos argumentos utilizados por Dom Jaime para o desmembramento da Diocese de Maringá, uma das possibilidades que encontrei diz respeito ao tamanho da diocese que ele tinha em mãos - 14.902,67 $\mathrm{km}^{2}$-, o que tornava inviável um trabalho efetivo, pois estavam 40 paróquias sob sua jurisdição, com uma população de mais de um milhão de habitantes. Esse

\footnotetext{
${ }^{71}$ PREFEITURA DO MUNICIPÍO DE PARANAVAÍ. Paranavaí, sua marca...sua história...sua gente. Paranavaí, 2013. p.20.

${ }^{72}$ MANOEL, Ivan A. O pêndulo da história: tempo e eternidade no pensamento católico (1800-1960). Maringá: Eduem, 2004, p. 45.

${ }^{73}$ CERTEAU, Michel. A Invenção do Cotidiano: Artes de Fazer. Petrópolis: Editora Vozes, 1998, p. 99

${ }^{74}$ MARINHO, Francisco Fernandes. A Diocese de Paranavaí: 40 anos de história evangelização 1968/2008. Maringá: CAHEL, 2008.
}

${ }^{75}$ MARINHO, op. cit., pp.30-31. 
número demandava investir muito tempo em visitas, que em muitos pontos da diocese, levava meses para voltar a acontecer. ${ }^{76}$

A nova diocese foi uma proposta aprovada de maneira coletiva pelos bispos da Província Eclesiástica, demonstrando que os argumentos utilizados por Dom Jaime foram convincentes. Em toda instituição há uma hierarquia a ser respeitada. A Igreja Católica prima pela hierarquia e esse fator garante a centralização do poder na pessoa do superior. Na região conhecida como Norte Novo o poder máximo estava nas mãos de Dom Jaime. E quais seriam os motivos que levariam um líder a dividir seu poder em vez de conservá-lo? Certamente a possibilidade de aumentá-lo, ou seja, Dom Jaime, um estrategista, viu a oportunidade de aumentar seu poder. Aqui mescla-se um movimento dentro da Igreja católica, como enunciado pelo Concílio Vaticano II, no qual por um lado temos a igreja se tornando mais presente na vida dos leigos e por outro a figura de Dom Jaime corroborando para que os anseios desta se tornassem palpáveis.

Em 1979 foi criada a Província Eclesiástica de Maringá. Esse processo iniciou-se em "1959 com a criação da Diocese de Campo Mourão que fazia parte da jurisdição do centro-oeste em Foz do Iguaçu e foi efetivamente instaurada pelo Papa João XXIII, começando a funcionar em 23 de abril de 1960". ${ }^{77}$ A fundação da Diocese de Paranavaí ocorreu em 1968. E por último, a partir deste contexto de desmembramentos de dioceses, foi criada a Diocese de Umuarama em 1973, desmembrada da Diocese de Campo Mourão. A sucessão de desmembramentos e ereções de novas dioceses não expressaram divisões, senão a ampliação das sucessivas fronteiras que permitiram a Dom Jaime ampliar seus domínios, tornando-se arcebispo da nova Província Eclesiástica.

\section{Considerações finais}

A pesquisa analisou o processo de institucionalização do catolicismo na região de Paranavaí, com ênfase na presença de Dom Jaime Luiz Coelho, bispo da Diocese de Maringá que, juntamente com os freis carmelitas, impulsionou o processo de ereção da diocese de Paranavaí. A análise dos documentos eclesiais e das narrativas dos freis, assim como a historiografia que trata do crescimento e desenvolvimento da região, permitiu entender que a região e

\footnotetext{
${ }^{76}$ ROBLES, op. cit., p. 238.

${ }^{77}$ PEREIRA, Marcia Maria. A Igreja católica em Maringá e a gestão de D. Jaime Luiz Coelho (1947-1980). Dourados, MS: UFGD, 2007. P. 82 Disponível em: http://repositorio.ufgd.edu.br/jspui/bitstream/prefix/157/1/ MarciaMariaPereira.pdf Acesso em: 27/05/2020.
} 
a Igreja Católica expandiram-se, concomitantemente, em meio aos conflitos gerados pela disputa de lideranças religiosas.

A pequena e novíssima região de Paranavaí, sufragânea da Diocese de Maringá, palco das atuações dos freis carmelitas e de Dom Jaime Luiz Coelho, constituiu-se num campo onde confluiu a instauração de mais uma diocese, a de Paranavaí, conforme a visão institucional de fronteiras sucessivas.

\section{Referências}

ARQUIVO SANTUÁRIO DO CARMO. Livro de tombo da paróquia São Sebastião, 1958, Paranavaí.

BACELLAR, Carlos. Fontes documentais: uso e mau uso dos arquivos. IN; PINSKY, Carla Bassanezi (org.). Fontes Históricas. $2^{\mathrm{a}}$ ed. São Paulo: Contexto, 2008.

BOURDIEU, Pierre.A Economia das trocas simbólicas. São Paulo. Perspectivas, 2011.

BOURDIEU, Pierre. 0 poder simbólico. 16ª ed. Rio de Janeiro: Bertrand Brasil, 2012.

BRITO, Angélica de. "A cruz vencerá o comunismo": o discurso anticomunista do jornal Folha Norte do Paraná (1962-1965). 152f. Programa de Pós Graduação em História, Universidade Estadual de Maringá, Maringá, 2015, p.56. Disponível em: http://repositorio.uem.br:8080/jspui/bitstream/1/2952/1/000220421.pdf Acesso: $20 / 05 / 2020$

CERTEAU, Michel. A Invenção do Cotidiano: Artes de Fazer. Petrópolis: Editora Vozes, 1998.

CHIES, Cláudia ; YOKOO, Sandra Carbonera. Colonização do Norte Paranaense: avanço da cafeicultura e problemas decorrentes deste processo. Rev. GEOMAE . Campo Mourão/PR. v.3 - n. 1.2012, pp.27 - 44. p.28 Disponível em: http://www.fecilcam. $\mathrm{br} /$ revista/index.php/geomae/article/view/204.\%20Acesso\%20em\%2020/05/2020. Acesso em:20/05/2020.

CNBB. Plano de Emergência para a Igreja do Brasil". Caderno № 1, 1963. São Paulo: Paulinas, 2004, p.15. Disponível em: http://portal.pucminas.br/imagedb/ documento/DOC_DSC_NOME_ARQUI20130906183649.pdf. Acesso em 21/08/2020. CÚRIA METROPOLITANA DE MARINGÁ, 1956, p.1. Maringá, 1956.

DIVISÃO regional do norte do Paraná. Portal dos municípios. Disponivel em: http:// observatoriogeograficoamericalatina.org.mx/egal10/Geografiasocioeconomica/ Geografiacultural/38.pdf. Acesso em: 27 maio 2020. 
ELIAS, Norbert. O Processo Civilizador: Formação do Estado e Civilização. RJ: Zahar, 1993.

FERREIRA, João Carlos Vicente. O Paraná e seus municípios. Cuiabá: J.C.V. Ferreira, 1999.

FOERST, Alberto, et al. As aventuras de 3 missionários alemães em Paranavaí. Trad. e notas Frei Wilmar Santin. Paranavaí, 2001, p.94-96. Disponível em: http:// ocarmelo.blogspot.com.br/ Acesso em: 20/08/ 2020. p.94.

FOERST, Alberto. Manuscritos. Trad. Dom Wilmar Santin, 2012, [s.1.], p.16

GARUTI, Selson. O poder no anel na diocese de Maringá. Dissertação de mestrado, Pontíficia Universidade Católica de São Paulo S.P. 2006. f. 111. p.65. Disponível em: https://sapientia.pucsp.br/bitstream/handle/1977/1/SelsonGarutti.pdf. Acesso em 07/05/2020.

GARUTTI, Selson. A constituição histórica da formação do catolicismo pioneiro em Maringá. Anais do II Encontro Nacional do GT História das Religiões e Religiosidades. Revista Brasileira das Religiões-ANPUH. Maringá-PR. V. 1, n. 3, 2009. ISSN 1983-2859. p. 15. Disponível em: http://www.dhi.uem.br/gtreligiao/ rbhr/a_constituicao_historica_da_formacao_do_catolicismo1.pdf Acesso em: 23/08/2020.

GOEVERT, Frei Ulrico. História e memórias de Paranavaí. Trad. e notas Frei Wilmar Santin, O Carm. Paranavaí: Livraria Nossa Senhora do Carmo, [1957]1992.

GOMES, Jesué Pinharanda. Carmelitas calçados. In: FRANCO, Jose Eduardo. Dicionário histórico das Ordens: Institutos religiosos e outras formas de vida consagrada católica em Portugal: Gradiva, 2008.

KNOBLAUCH, Joaquim. Os 25 anos dos carmelitas da Província Germaniae Superioris no Brasil. Paranavaí-PR, [s.n.] 1976.

MANOEL, Ivan A. O pêndulo da história: tempo e eternidade no pensamento católico (1800-1960). Maringá: Eduem, 2004.

MARINHO, Francisco Fernandes. A Diocese de Paranavaí: 40 anos de história evangelização 1968/2008. Maringá: CAHEL, 2008.

NOELLI, Francisco S.; MOTA, Lúcio T. A pré-história da Região onde se encontra Maringá, Paraná. In: Maringá e o Norte do Paraná. Estudos de história regional. DIAS, Reginaldo B.; GONÇALVES, José Henrique Rollo (org.). Maringá: EDUEM, 1999. 
PEDRAS, Beatriz Junqueira. Uma leitura do I Livro de Tombo do Convento do Carmo em Salvador: contribuição à construção histórica da Ordem dos Carmelitas na Bahia Colonial. Dissertação de mestrado. Escola de Ciência da Informação, Belo Horizonte-MG, 2000, p.44. Disponível em:https://repositorio.ufmg.br/ bitstream/1843/LHLS-69URYB/1/mestrado_-_beatriz_junqueira_pedras.pdf Acesso em: 23/08/2020.

PEREIRA, Márcia Maria. A Igreja Católica em Maringá e a gestão de D. Jaime Luiz Coelho (1947-1980). Dourados, MS: UFGD, 2007.

PREFEITURA DO MUNICIPÍO DE PARANAVAÍ. Paranavaí, sua marca...sua história...sua gente. Paranavaí, 2013.

PRIORI, Ângelo. O levante dos posseiros: a revolta camponesa de Porecatu e a ação do Partido Comunista Brasileiro no campo. Maringá: Eduem, 2011, p. 24.

PRIORI, Ângelo [et al.]. História do Paraná: séculos XIX e XX. Maringá: Eduem, 2012. RECCO, Rogério. Clareira Flamejante- O norte do Paraná antes e depois do advento da energia elétrica. Maringá: Gráfica e Editora Midiograf, 2007 45. Disponível em: https://www.yumpu.com/pt/document/read/63229706/clareira-flamejanteo-norte-do-parana-antes-e-depois-do-advento-da-energia-eletrica. Acesso 22/05/2020.

ROBLES, Orivaldo, Pe. A Igreja que brotou da mata. Maringá: PR: Dental Press, 2007. ROSENDAHL, Zeny. Primeira a obrigação depois a devoção: estratégias espaciais da Igreja Católica no Brasil de 1500 a 2005. Rio de Janeiro: EdUERJ, 2012.

ROSENDAHL, Z. Território e territorialidade: uma perspectiva geográfica para o estudo da religião. Anais do X Encontro de Geógrafos da América Latina - 20 a 26 de março de 2005 - Universidade de São Paulo, 20-26 março 2005. Disponivel em: http://observatoriogeograficoamericalatina.org.mx/egal10/ Geografiasocioeconomica/Geografiacultural/38.pdf. Acesso em: 27 maio 2020.

SANTOS, Pe. Marcos Roberto Almeida dos. "Artigo de padre Marcos Roberto: Cem anos de dom Jaime- O centenário de um paulista”. Cúria Metropolitana de Maringá, 2016, Maringá. Disponível em: http://arquidiocesedemaringa.org.br/noticias/704/ artigo-de-padre-marcos-roberto-cem-anos-de-dom-jaime-o-centenario-de-umpaulista Acesso em: 05/05/2020.

SEVCENKO, N. (Org.) O Prelúdio Republicano, Astúcias da Ordem e Ilusões do Progresso. In: NOVAIS, F. A. (coord.). História da Vida Privada no Brasil. Vol. 3. São Paulo: Companhia das Letras, 1998, pp. 7-48. 
SILVA, P. M. S. da. História de Paranavaí. Paranavaí: Fundo Municipal de Cultura, 2014.

THOMPSON, E. P. Costumes em comum. São Paulo: Companhia das Letras, 1998.

Artigo recebido para publicação em 09/06/2020 Artigo aprovado para publicação em 04/09/2020 